\title{
música do futuro
}

A que não aguentamos esperar

vai nos ensinar.

Brilha, é incerta, longe.

A que deixamos vir até nós, não nos espera,

não vem até nós,

não volta até nós,

fica a caminho.

Não nos pertence,

não pergunta por nós,

não quer saber de nós,

não nos diz nada,

é parte que não nos cabe.

Não esteve,

não está nem aí para nós,

nunca esteve aí,

nunca está aí,

nunca está. 